\title{
PENGARUH STRATEGI THINK-TALK-WRITE (TTW) \\ BERBASIS KONTEKSTUAL TERHADAP KETERAMPILAN \\ PROSES SAINS SISWA KELAS VII MTS NW WANASABA \\ LOMBOK TIMUR TAHUN PELAJARAN 2014/2015
}

\author{
Bq. Kurnia ${ }^{1}$ dan Bahtiar ${ }^{2}$ \\ 1Jurusan Tadris IPA Biologi FITK IAIN Mataram \\ 2 Dosen Jurusan Tadris IPA Biologi FITK IAIN Mataram
}

\begin{abstract}
Abstrak
Penelitian ini bertujuan untuk mengetahui pengaruh strategi pembelajaran Think-Talk-Write berbasis kontekstual terhadap keterampilan proses sains siswa kelas VII MTs NW Wanasaba Lombok Timur Tahun Pelajaran 2014/2015. Desain penelitian yang digunakan adalah true eksperimental yaitu Pretest-Posttest Control Group Design dengan pendekatan kuantitatif. Populasi dalam penelitian ini adalah semua siswa kelas VII MTs NW Wanasaba dengan jumlah 80 orang siswa yang terbagi dalam 3 kelas. Sedangkan sampel diambil secara simple random sampling dan sampel yang terpilih adalah kelas VIIC sebagai kelass eksperimen dan kelas VIIB sebagai kelas kontrol. Instrument yang digunakan untuk mengukur keterampilan proses sains siswa adalah lembar observasi dan tes, masing-masing instrument disusun berdasarkan indikator keterampilan proses sains yang diamati. Hasil analisis data observasi menggambarkan bahwa ada perbedaan keterampilan proses sains antara kelas eksperimen (VIIC) dan kelas kontrol (VIIB) yaitu kelas eksperimen memiliki skor observasi $82,66 \%$ sangat tinggi dari pada kelas kontrol 23,33\%. Sedangkan hipotesis di uji menggunakan rumus uji t. Berdasarkan hasil pengolahan data posttest diperoleh t-hitung $\geq \mathrm{t}$ tabel atau 4,79 22,01 maka dapat disimpulkan bahwa ada pengaruh strategi Think-Talk-Write berbasis kontekstual terhadap keterampilan proses sains siswa kelas VII MTs NW Wanasaba Lombok Timur Tahun Pelajaran 2014/2015.
\end{abstract}

Kata kunci: Strategi Think-Talk-Write, Kontekstual, dan Keterampilan Proses Sains 


\section{PENDAHULUAN}

Pendidikan memiliki peran yang sangat penting dalam pembentukan sumber daya manusia (SDM), maka peningkatan mutu pendidikan merupakan hal yang wajib dilakukan secara berkesinambungan guna menjawab perubahan zaman. Masalah mutu pendidikan tentulah sangat berhubungan dengan proses pembelajaran. Selama ini proses pembelajaran dilembagalembaga pendidikan masih banyak yang mengandalkan cara-cara lama dalam penyampaian materinya. Sehingga siswa merasa dituntut untuk menghafal fakta-fakta yang diberikan oleh guru.

Tindakan guru bukanlah untuk mempersiapkan anak untuk menghafal sejumlah materi akan tetapi merancang pembelajaran yang memungkinkan siswa menemukan sendiri materi yang harus dipahaminya. Belajar merupakan proses mental seseorang yang tidak terjadi secara mekanis, akan tetapi perkembangan diarahkan pada intelektual, mental emosional, dan kemampuan individu yang utuh. Belajar akan lebih bermakna jika siswa mengalami sendiri apa yang dipelajarinya, bukan sekedar mengatahuinya. Ada kecenderungan untuk kembali pada pemikiran bahwa anak akan belajar lebih baik jika lingkungan diciptakan alamiah. Proses pembelajaran berlangsung alamiah dalam bentuk kegiatan siswa bekerja dan mengalami, bukan mentransfer pengetahuan dari guru ke siswa.

Peran guru dalam pendidikan sangatlah kompleks, guru merupakan key person in classroom, sehingga guru memiliki peran yang sangat vital dan fundamental dalam membimbing, mengarahkan, dan mendidik. Selain menyiapkan strategi pembelajaran, salah satu peran guru yang tidak bisa diabaikan adalah sebagai evaluator, yakni guru berperan dalam melaksanakan penilaian, dan menilai pekerjaan siswa. Dengan penilaian guru dapat mengetahui keberhasilan pencapaian tujuan pembelajaran, penguasaan siswa terhadap pembelajaran, serta ketepatan dan keefektifan strategi mengajar. Tujuan lain dari penilaian diantaranya adalah untuk mengetahui kedudukan siswa di dalam kelas atau kelompoknya. Dengan penilaian guru dapat mengklasifikasi apakah seorang siswa termasuk kelompok siswa

44 BIOTA: Jurnal Tadris IPA Biologi FITK IAIN Mataram 
yang pandai, sedang, kurang, atau cukup baik di kelasnya jika dibandingkan dengan teman-temannya.

Berdasarkan hasil observasi dan wawancara peneliti dengan salah satu guru IPA terkait proses pembelajaran dan sistem penilaian aspek hasil belajar di MTs NW wanasaba, bahwa strategi yang biasa digunakan adalah strategi konvensional yang menyebabkan siswa kurang berperan aktif dalam pembelajaran, sehingga sistem penilaian terhadap hasil belajar lebih banyak mengukur aspek kognitif berupa hapalan, guru kurang menerapkan strategi yang dapat membantu untuk membangun pengetahuan siswa seperti: strategi observasi, strategi eksperimen, dan strategi laboratorium experience. Selain itu guru kurang memberikan latihan-latihan soal yang menantang seperti: melatih kemampuan atau keterampilan berpikir tingkat tinggi, keterampilan proses sains siswa, keterampilan psikomotor siswa, dan keterampilan dasar ilmiah atau berinkuiri. Guru menjelaskan sains hanya sebatas produk dan sedikit proses. Salah satu penyebab yang dijadikan alasan adalah padatnya materi yang harus dibahas dan diselesaikan berdasarkan kurikiulum yang berlaku. Siswa hanya dituntut untuk lebih banyak mempelajari konsep-konsep dan prinsip-prinsip sains secara hafalan, Hal ini dibuktikan dengan hasil MID pada semester genap.

Tabel 1

Nilai MID siswa kelas VIIB MTs. NW Wanasaba Tahun Pelajaran 2014/2015

\begin{tabular}{|c|c|c|c|c|c|c|}
\hline No & Kelas & $\begin{array}{c}\text { Jumlah } \\
\text { siswa }\end{array}$ & KKM & $\begin{array}{c}\text { Nilai } \\
\text { Rata- } \\
\text { rata }\end{array}$ & Tuntas & $\begin{array}{c}\text { Tidak } \\
\text { tuntas }\end{array}$ \\
\hline 1 & VIIB & 24 orang & 70 & 68,41 & $\begin{array}{c}9 \text { orang }= \\
37,5 \%\end{array}$ & $\begin{array}{c}15 \text { orang } \\
62,5 \%\end{array}$ \\
\hline
\end{tabular}


Data tersebut menenjukkan bahwa nilai ulangan harian pada mata pelajaran IPA siswa kelas VIIB masih berada di bawah KKM yang ditentukan yaitu 70. Adapun nilai rata-rata siswa adalah 68,41 . Dari 24 siswa hanya 9 orang siswa $(37,5 \%)$ yang mencapai KKM, dan sisanya 15 orang siswa $(62,5 \%)$ belum mencapai KKM. Berdasarkan nilai rata-rata siswa yang berada dibawah standar menandakan bahwa proses pembelajaran disekolah belum dilakukan secara maksimal sehingga berpengaruh terhadap hasil belajar siswa. Rendahnya prestasi belajar siswa dibidang sains berhubungan dengan proses pembelajaran yang belum memberikan peluang bagi siswa untuk mengembangkan kemampuan bernalar secara kritis.

Penilaian proses dan hasil belajar IPA menuntut teknik dan cara-cara penilaian yang komprehensif. Disamping aspek hasil belajar yang di nilai harus menyeluruh, tekhnik penilaian dan instrument penilaian seyogyanya lebih bervariasi.

Salah satu penilaian yang dapat dilakukan oleh guru IPA/ sains dalam pelaksanaan proses pembelajaran adalah keterampilan proses sains (KPS). Penilaian keterampilan proses sains ini sesuai dengan peraturan menteri (Permen) 22 tahun 2006 tentang standar isi (SI), dimana ilmu pengetahuan alam merupakan ilmu yang lahir dan berkembang berdasarkan observasi dan eksperimen. Dengan demikian, belajar IPA tidak cukup hanya dengan menghapal fakta dan konsep yang sudah jadi, tetapi dituntut pula untuk menemukan fakta-fakta dan konsepkonsep tersebut melaui observasi dan eksperimen. Melalui pendidikan/pengajaran IPA siswa diajak untuk melakukan eksplorasi alam. Dengan proses inilah dapat dikembangkan keterampilan proses sains, sehingga pengalaman tentang sains dapat diperoleh dan memudahkan siswa dalam memahami konsep-konsep sains karena memberikan kesempatan kepada siswa bekerja dengan ilmu pengetahuan, tidak sekedar menceritakan atau mendengarkan cerita tentang ilmu pengetahuan. Hal ini menyebabkan siswa menjadi lebih aktif. Berdasarkan uraian diatas maka peneliti tertarik untuk meneliti tentang: "Pengaruh Strategi TTW (Think-Talk-Write) berbasis

46 BIOTA: Jurnal Tadris IPA Biologi FITK IAIN Mataram 
kontekstual terhadap keterampilan proses sains siswa kelas VII MTs NW Wanasaba Lombok Timur Tahun Pelajaran 2014/2015".

\section{METODE PENELITIAN}

\section{Jenis dan desain penelitian}

Jenis penelitian ini adalah penelitian eksperimen yaitu penelitian yang dilakukan untuk mencari pengaruh terhadap perlakuan yang diberikan. Desain penelitian yang digunakan adalah Pretest-Posttest Control Group Design yaitu desain penelitian yang menggunakan kelas eksperimen sebagai kelas percobaan dan kelas kontrol sebagai kelas pembanding. Kedua kelas diberikan tes sebelum dan setelah pembelajaran.

\section{Populasi dan sampel}

Populasi dalam penelitian ini adalah seluruh siswa kelas VII MTs NW Wanasaba dengan jumlah siswa 80 orang yang terbagi dalam tiga kelas. Sedangkan sampel penelitian dipilih dengan tehnik simple random sampling, hasilnya kelas VII C sebagai kelas eksperimen dan kelas VIIB sebagai kelas kontrol.

\section{Instrument penelitian}

Instrument yang digunakan untuk memperoleh data tentang keterampilan proses sains adalah lembar observasi dan tes. Lembar observasi digunakan untuk mengamati setiap indicator keterampilan proses sains yang dapat dilakukan oleh siswa, sedangkan tes keterampilan proses sains dibuat dalam bentuk uraian dan pilihan ganda dengan jumlah 10 butir soal yang mencakup 5 jenis indikator keterampilan proses sains.

\section{Hipotesis penelitian}

Hipotesis yang diajukan yaitu ada pengaruh strategi think talk write berbasis kontekstual terhadap keterampilan proses 
sains siswa kelas VII MTs NW Wanasaba Lombok Timur Tahun Pelajaran 2014/2015.

\section{Teknik analisis data}

Untuk menguji hipotesis yang diajukan digunakan teknik analisis data dengan uji t. Untuk dapat melakukan uji t terlebih dahulu dilakukan uji asumsi seperti uji normalitas dan uji homogenitas.

\section{HASIL PENELITIAN DAN PEMBAHASAN}

Berdasarkan analisis seluruh data hasil penelitian yang diperoleh melalui lembar observasi dan tes diuraian berikut ini:

Tabel 2

Data hasil observasi KPS kelas eksperimen dan control

\begin{tabular}{|c|c|c|c|c|c|c|c|}
\hline \multirow{2}{*}{$\begin{array}{l}\mathrm{N} \\
\mathrm{o}\end{array}$} & \multirow{2}{*}{ Indikator KPS } & \multicolumn{3}{|c|}{ Kelas eksperimen } & \multicolumn{3}{|c|}{ Kelas kontrol } \\
\hline & & Skor & $\%$ & Kategori & Skor & $\%$ & Kategori \\
\hline 1 & Observasi & 28 & \multirow{5}{*}{$\begin{array}{l}=\frac{124}{150} \times 100 \% \\
=82,66 \%\end{array}$} & \multirow{5}{*}{$\begin{array}{c}\text { Sangat } \\
\text { baik }\end{array}$} & 16 & \multirow{5}{*}{$\begin{array}{r}\frac{44}{150} \times 100 \% \\
=23,33 \%\end{array}$} & \multirow{5}{*}{ Kurang baik } \\
\hline 2 & Klasifikasi & 29 & & & 14 & & \\
\hline 3 & Prediksi & 19 & & & 7 & & \\
\hline 4 & Interpretasi & 23 & & & 7 & & \\
\hline 5 & Komunikasikan & 25 & & & 0 & & \\
\hline & $\sum$ & 124 & & & 44 & & \\
\hline
\end{tabular}

Berdasarkan data hasil lembar observasi keterampilan proses sains diatas diketahui bahwa kelas eksperimen diperoleh skor 82,66\% masuk dalam kategori sangat baik, artinya strategi TTW (think talk write) berbasis kontekstual berpengaruh terhadap keterampilan proses sains siswa. Sedangkan kelas kontrol memperoleh skor 23,33\% masuk dalam kategori kurang baik, artinya metode ceramah tidak berpengaruh terhadap keterampilan proses sains siswa. Hasil tersebut menunjukkan perbedaan dalam penggunaan strategi think talk write berbasis

48 BIOTA: Jurnal Tadris IPA Biologi FITK IAIN Mataram 
kontekstual dengan metode ceramah terhadap keterampilan proses sains siswa.

Sedangkan untuk menguji hipotesis yang diajukan yaitu $\mathrm{Ha}$ (ada pengaruh pemberian strategi Think Talk Write berbasis kontekstual terhadap keterampilan proses sains siswa), digunakan rumus uji t. Untuk bisa melakukan uji t harus diawali dengan serangkaian pengetesan atau pengujian yang lain seperti uji homogenitas dan uji normalitas.

\section{Uji homogenitas}

\begin{tabular}{|c|c|}
\hline Kelas & Varians $\left(S^{2}\right)$ \\
\hline Eksperimen & 28,71 \\
\hline Kontrol & 17,82 \\
\hline
\end{tabular}

$$
\begin{aligned}
& \mathrm{F}=\frac{\text { varians terbesar }}{\text { varians terkecil }}=\frac{28,7}{17,82}=1,61 \\
& \mathrm{db}(\text { pembilang) } \\
& =\mathrm{n}-1=24-1=23 \\
& \mathrm{db}_{\text {(penyebut) }}=\mathrm{n}-1=26-1=25 \\
& \mathrm{~F}_{\text {tabel }}(\alpha=0,05)=2,000
\end{aligned}
$$

Dari hasil analisis uji homogenitas menunjukkan bahwa kedua data memiliki varians yang homogen karena $F_{\text {hitung }} \leq F_{\text {tabel }}$ atau $(1,61) \leq(2,00)$. Artinya kelompok-kelompok yang dibandingkan merupakan kelompok-kelompok yang mempunyai varians homogen.

\section{Uji normalitas}

\begin{tabular}{|c|c|c|}
\hline Kelas & $\chi^{2}$ hitung & $\chi^{2}$ tabel \\
\hline Eksperimen & 5,502 & 11,070 \\
\hline Kontrol & 6,12 & 11,070 \\
\hline
\end{tabular}


Sedangkan dari hasil analisis uji normalitas menunjukkan bahwa data terdistribusi normal karena $\chi^{2}$ hitung $6,48 \leq \chi^{2}$ tabel 11,07, maka strategi TTW (Think Talk Write) berbasis kontekstual yang digunakan pada sampel dapat digeneralisasikan atau digunakan pada populasi.

Setelah melalui persyaratan pengujian tersebut maka selanjutnya dapat dilakukan analisis uji t. Rumus uji $t$ yang digunakan adalah rumus Polled varians karena sampel dalam penelitian ini memiliki $n_{1} \neq n_{2}$, varians homogen $\left(\sigma_{1}^{2}=\sigma_{2}^{2}\right)$, besarnya $\mathrm{dk}=n_{1}+n_{2}-2$

$$
\begin{aligned}
& t=\frac{\bar{x}_{1}-\bar{x}_{2}}{\sqrt{\frac{\left(n_{1}-1\right) S_{1}^{2}+\left(n_{2}-1\right) S_{2}^{2}}{n_{1}+n_{2}-2}\left(\frac{1}{n_{1}}+\frac{1}{n_{2}}\right)}} \\
& t=\frac{73,87-68,53}{\sqrt{\frac{(24-1) 19,12+(26-1) 17,72}{24+26-2}\left(\frac{1}{24}+\frac{1}{26}\right)}} \\
& t=\frac{5,34}{\sqrt{\frac{439,76+443}{48}(0,04+0,03)}} \\
& t=\frac{5,34}{\sqrt{18,39(0,07)}} \\
& t=\frac{5,34}{\sqrt{1,2873}} \\
& t=\frac{5,34}{1,1345}=4,70
\end{aligned}
$$

Berdasarkan pengujian data diatas diperoleh $t$ hitung 4,70 maka untuk mencari t-tabel terlebih dahulu ditentukan $\mathrm{dk}=$ $\mathrm{n}_{1}+\mathrm{n}_{2}-2=24+26-2=48$ pada taraf signifikan $5 \%$ maka ditemukan t-tabel sebesar 2,01. Jika dibandingkan antara keduanya maka $t$ hitung $\geq \mathrm{t}$ tabel atau 4,70 $\geq 2,01$ sehingga dapat

50 BIOTA: Jurnal Tadris IPA Biologi FITK IAIN Mataram 
disimpulkan bahwa hipotesis alternatif (Ha) yang diajukan peneliti diterima dan hipotesis nol (Ho) ditolak. Artinya, ada pengaruh penggunaan strategi TTW (Think Talk Write) berbasis kontekstual terhadap keterampilan proses sains siswa kelas VII MTs NW Wanasaba Tahun Pelajaran 2014/2015.

Strategi TTW (Think Talk Write) berbasis kontekstual dalam penelitian ini ada pengaruhnya terhadap keterampilan proses sains siswa karena dalam proses pembelajarannya siswa dituntut untuk menguasai dan mengembangkan kemampuan dalam dirinya melalui keterampilan proses mengobservasi, klasifikasi, interpretasi, prediksi dan berkomunikasi, yang terlebih dahulu dilakukan secara sendiri-sendiri agar siswa bebas mengeluarkan ide-idenya untuk menyelesaikan permasalahan yang diberikan, kemudian siswa melakukan diskusi untuk menyesuaikan pemahaman individu dengan teman kelompoknya, selain itu diskusi dilakukan untuk mengambil jawaban terbaik. Setelah berdiskusi siswa mempresentasekan hasil diskusinya di depan kelas dan akhirnya menuliskan hasil belajar yang di peroleh dengan menggunakan bahasanya sendiri, sehingga siswa lebih memahami dan mengingat materi yang dipelajari.

Sebuah keterampilan akan terbentuk hanya melalui proses berulang-ulang. Siswa tidak akan terampil (misalnya untuk mengobservasi, klasifikasi, menarik kesimpulan, prediksi dan berkomunikasi) bila tidak ada peluang untuk melakukannya sendiri proses tersebut secara terus-menerus. Strategi TTW (Think Talk Write) berbasis kontekstual sesuai digunakan untuk keterampilan proses sains karena memberikan kesempatan kepada siswa untuk bekerja sendiri dan bekerja dengan kelompok. Pengalaman langsung yang diberikan akan membantu siswa lebih mudah memahami dan mengingat materi yang dipelajari dalam waktu yang relatif lama.

Selain itu keterampilan proses sains dengan pembelajaran kontekstual memiliki tujuan yang sama yaitu mendidik siswa agar dapat menemukan sendiri konsep-konsep IPA yang dipelajari melalui proses ilmiah. Mengingat kegiatan inti dalam pembelajaran kontekstual adalah inkuiri (penemuan) maka 
strategi Think Talk Write berbasis kontekstual sesuai digunakan untuk keterampilan proses sains siswa karena kegiatan-kegiatan dalam pembelajaran kontekstual (inkuiri) sama dengan kegiatan pada keterampilan proses sains.

Namun, setiap pembelajaran tidak ada yang sempurna karena selalu memiliki kekurangan ataupun kelebihan. Seperti strategi TTW (Think Talk Write) berbasis kontekstual. Adapaun kekurangan yang dimiliki adalah 1) membutuhkan waktu yang lama untuk menggunakan strategi tersebut, 2) dalam proses pembelajaran dibutuhkan komunikasi dan siswa mudah melepaskan diri dalam keterlibatan diskusi. Adapun kelebihan strategi ini adalah :1) Mendidik siswa lebih mandiri, 2) Mendidik siswa berpikir kritis 3) Mendidik siswa lebih percaya diri, 4) Melatih siswa untuk bekerjasama, 5 ) Melatih siswa untuk menuangkan ide-ide melalui tulisan maupun lisan, 6) Siswa menjadi lebih aktif.

\section{KESIMPULAN}

Berdasarkan hasil analisis data dengan menggunakan rumus uji t diperoleh harga thitung $(4,79) \geq t$ tabel $(2,01)$ dengan $\alpha=5 \%$ sehingga dapat disimpulkan bahwa ada pengaruh strategi TTW (Think Talk Write) berbasis kontekstual terhadap keterampilan proses sains siswa kelas VII MTs NW Wanasaba tahun pelajaran 2014/2015.

\section{DAFTAR PUSTAKA}

Ahmad Muhlisin, dalam "Pengembangan Perangkat Pembelajaran IPA Terpadu Berbasis Kontekstual Dengan Model Pembelajaran Kooperatif Tipe Student Team Achievement Division (STAD) Tema Polusi Udara", Journal Of Educational And Evaluation UNS, online diakses selasa 06 mei 2014.

Baiq Fatmawati, dalam "Menilai Keterampilan Proses Sains Siswa Melalui Metode Pembelajaran Langsung",STKIP

52 BIOTA: Jurnal Tadris IPA Biologi FITK IAIN Mataram 
Hamzanwadi Selong, online diakses pada hari selasa 06 mei 2014.

Daryanto. 1998. Kamus Lengkap Bahasa Indonesia, Surabaya: Apollo.

Dimyati. 2006. Belajar dan Pembelajaran, Jakarta: PT Rieneka Cipta.

Euis Yuniastuti, dalam "Peningkatan Keterampilan Proses, Motivasi, dan Hasil Belajar Biologi Dengan Strategi Pembelajaran Inkuiri Terbimbing Pada Siswa Kelas VII SMP Kartika V-1 Balikpapan", online diakses selasa 06 mei 2014.

I Ketut Wardana. Dkk, dalam Pengaruh Model Kontekstual Terhadap Keterampilan Proses Sains dan Hasil Belajar Sains Pada Siswa Kelas IV SD Gugus V Dr Soetomo, e journal program pascasarjana Universitas Pendidikan Ganesha (volum 3 tahun 2013).

Imama Wahidah, dalam Penerapan Strategi Think Talk Write (TTW) Untuk Meningkatkan Hasil Belajar Matematika Siswa Kelas VII Smp Brawijaya Smart School (BSS,

Indrawati. 1999. Keterampilan Proses Sains/IPA Tinjauan Kritis Dari Teori Ke Praktis, Bandung: Pusat Pengembangan Penetaran Guru IPA.

M Ngalim Purwanto. 2004. Prinsip-Prinsip dan Teknik Evaluasi Pengajaran, Bandung: Remaja Rosdakarya.

M Yamin. 2008. Taktik Mengembangkan Kemampuan Individual Siswa, Jakarta : Gaung Persada Press.

Mahmud. 2011. Metode Penelitian Pendidikan, Bandung: Pustaka Setia.

Miftahul Huda. 2013. Model-Model Pengajaran dan Pembelajaran: isu-isu metodis dan Paradigmati, Yogyakarta: Pustaka Pelajar Offset.

Neohi nasution dan Adi surianto. 2007. Evaluasi Pembelajaran, Jakarta: Universitas terbuka.

Purwanto. 2010. Prinsip-prinsip dan Teknik Evaluasi Pembelajaran, Bandung: Remaja Rosdakarya.

Semiawan. 2012. Pendekatan Keterampilan Proses: Bagaimana Mengaktifkan Siswa dalam Belajar, Jakarta: Penerbit Grasindo. 
Soetardjo dan Soejitno. 1998. Proses belajar Mengajar dengan Pendekatan Keterampilan Proses, Surabaya: SIC.

Subana, dkk.. 2000. Statistik pendidikan, Bandung: Pustaka setia.

Sugiyono. 2011. Metode penelitian kombinasi Bandung: Alfabeta.

Sugiyono. 2006. Metode Penelitian Kuantitatif Kualitatif dan $R \& D$, Bandung: Alfabeta.

Sugiyono. 2010. Metodologi Penelitian Pendidikan Pendekatan Kualitatif, Kuantitatif, R\&D. Bandung: Alfabeta.

Suharsimi Arikunto. 2010. Prosedur Penelitian, Jakarta: Rieneka Cipta.

Sumarna Surapranata. 2009. Analisis, Validitas, Reliabilitas Dan Interpretasi Hasil Tes, Bandung: Remaja rosdakarya.

Suseli. 2010. dalam "Perbandingan Hasil Belajar Matematika Siswa yang menggunakan Think Talk Write(TTW) dengan Metode Ekspositori (Studi Eksperimen Siswa Kelas VII SMP Negeri I Balongan Indramayu" IAIN Syekh Nurjati Cirebon, online diakses selasa 06 mei 2014.

Syaiful Bahri Djamarah. 2010. Guru \& Anak Didik dalam intraksi edukatif, Jakarta: Rineka Cipta.

Trianto. 2008. Mendesain Pembelajaran Kontekstual (Contextual Teaching and Learning) di Kelas, Jakarta: pustaka publisher

Udin Saefudin Sa'ud. 2008. Inovasi Pendidikan,Bandung: Alfabet

Wina Sanjaya. 2009. Penelitian Tindakan Kelas, Jakarta: Kencana Prenada Media Group.

Wina Sanjaya. 2006. Strategi Pembelajaran Berorientasi Standar Proses Pendidikan, Jakarta: Kencana.

Yulia susanti, dalam Penerapan Strategi Pembelajaran Kooperatif Tipe Think Talk Write Pada Konsep Ekosistem Di Kelas Vii Smp Negeri 3 Cibalong Kabupaten Tasikmalaya, online diakses selasa 06 Mei 2014.

Zainal Aqib. 2013. Model-Model, Media dan Strategi Pembelajaran Kontekstual (Inovatif), Bandung: Yrama Widya.

54 BIOTA: Jurnal Tadris IPA Biologi FITK IAIN Mataram 